\title{
Analysis of student's achievement motivation in learning chemistry
}

\author{
Beta Wulan Febriana \\ Department of Chemistry Education \\ Faculty of Mathematics and Natural Sciences Indonesian Islamic University \\ Jl. Kaliurang Km 14,5 Yogyakarta 55584, INDONESIA \\ E-mail: betawulanfebriana@uii.ac.id
}

\begin{abstract}
The aim of the study is to determine the effect of student's achievement motivation toward learning chemistry. This research was conducted at SMK Kesehatan Rahani Husada. The descriptive method was used in this research. The data was collected using test for student's cognitive achievement and questionnaire for achievement motivation. Data was analyzed using descriptive analysis techniques. The results show that achievement motivation on XI grade of SMK Kesehatan Rahani Husada students was in the category of achievement motivation "high" at $47,54 \%$. Moreover, achievement motivation tends effect is random to student's achievement.
\end{abstract}

\section{Introduction}

Nowadays, Indonesia is in the era of the Masyarakat Ekonomi ASEAN (MEA). It means, that quality of education in Indonesia must be improved. All of the learning outcomes must have a capability to compete with foreign students all over the world. In fact, from PISA and TIMMS, the Indonesian student score in science and math is almost at the lowest level among OECD country. [1]

Improving the quality of education in Indonesia cannot be separated from the learning process. Teaching and learning activities are fundamental conducted in schools. It means that the success or failure of education goals depend on how the learning process experienced by students.

The achievement of the goals of education is the principal task of someone who deals directly with policy making and implementer education. According to Akbar and Hawadi (2001), the achievement of educational success can be realized by many factors that influence the internal factor of student or external factor of student. The achievement of learning that is achieved by the students is the factor of the interaction between both of those factors. [2]

Motivation has an important role in learning. Student's achievement is related to the way of thinking, feeling and behavior of students [3]. Students who have problems at school, they show the level of motivation is low. Teachers need to seek an increase in student's achievement motivation by providing support in the form of awards/ reinforcement for his achievements, paying attention to awareness, giving feedback and making students have felt the ability. [4] 
In vocational school in health, SMK Kesehatan Rahani Husada, the student's achievement motivation in learning process is still lacking. Students are less enthusiasm in chemistry learning, especially hydrocarbon derivatives. Many students still do not pay attention when teachers teach. It signifies that they have low achievement motivation. Motivation becomes the background for someone to get a high achievement.

The chemistry material learnt by students was hydrocarbon derivatives. In this material, students study for naming an organic compound by International Union of Pure and Applied Chemistry (IUPAC). Hydrocarbons are the simplest organic compound, consist of carbon and hydrogen. Hydrocarbon can be straight chain, branched chain or cyclic molecules. Hydrocarbon derivatives contain carbon atoms and hydrogen atoms with specific group of atom attached. By the end, students will have discovered some general properties of hydrocarbon derivatives. The characteristic of this material is abstract. Students must be imagine to give name of an organic compound as a tree. In a tree, there are tree as longest chain (parent chain) and branch as alkyl group. Students must be determine the longest chain and branch in an organic compound. Hydrocarbon derivatives contain many kinds of concepts.

According to Uno [5], achievement motivation is very influential on the performance. Uno argues that achievement motivation can help in understanding and explaining of students. The important role of achievement motivation are, (1) to determine the things that can be used as reinforcement in the achievement, (2) to clarify the purpose of achievement to be achieved, (3) to determine the range of control toward stimulation of achievement, and (4) to determine the persistence of learning.

Student who has high motivation, they maybe have high motivation too. The intensity of the efforts increase, the higher the learning results can be obtained. To be motivated means to be moved to do something. A person who feels no impetus or inspiration to act is thus characterized as unmotivated, whereas someone who is energized or activated toward an end is considered motivate [6]. This study aimed to analyze whether achievement motivation influence student's achievement in aspects of knowledge.

\section{Methods}

This research is a descriptive research. According to Sugiyono [7], descriptive research is conducted to determine the value of an independent variable, either one or more variables (independent) without making comparisons, or connect with other variables. The research subject is XI grade student of SMK Kesehatan Rahani Husada. The population in this study consisted of 120 students with the sample of 30 students. A sampling technique that used is purposive sampling. The asssessment instruments used cognitive test and questionnaire of achievement motivation. Both of instrument validated by two lecturers and two vocational school teachers. Cognitive test and achievement motivation questionnaire is "fit for use." The achievement motivation is measured using Likert scale with four options, strongly agree, agree, disagree, and strongly disagree. [8] 


\section{Results and Discussion}

Based on achievement motivation questionnaire, someone who has high achievement motivation always has a responsibility in carrying out the task. Students assume the assignment of teachers solely provide the benefit of the students themselves. Students do not consider that the assignment of teachers is the burden so that students do the work as well as possible. In addition, students carry out tasks with high targets. That is, students really exert all their efforts in order to set targets to be achieved. [9]

Students who has high achievement motivation like to try new things, he always be curious for something that is new and always want to fullfill thing that he wants. Extrinsic factors that affect student achievement motivation in that they are always trying to outperform others. With the ability to outperform others (peers), they tend to feel "considered" and feel great compared to his friend. When a great feeling occurs, they'll get compliments from others. It means that self-efficacy is an essential motive to learn [10].

The percentage of achievement motivation indicator of students is shown in Fig 1. Based on Fig 1., the highest percentage of achievement motivation for indicator is "study hard to get best scores" as $14,33 \%$. It means that students have self-motivation to get high scores in every task that they were done. Scores are very important things for them. On the other hands, the lower percentage is around 6,77\%. This indicator is "happy trying to something new." It can happen because they are seldom to do experiment activities. Although they are doing some experiments, they just do it without meaningful learning.

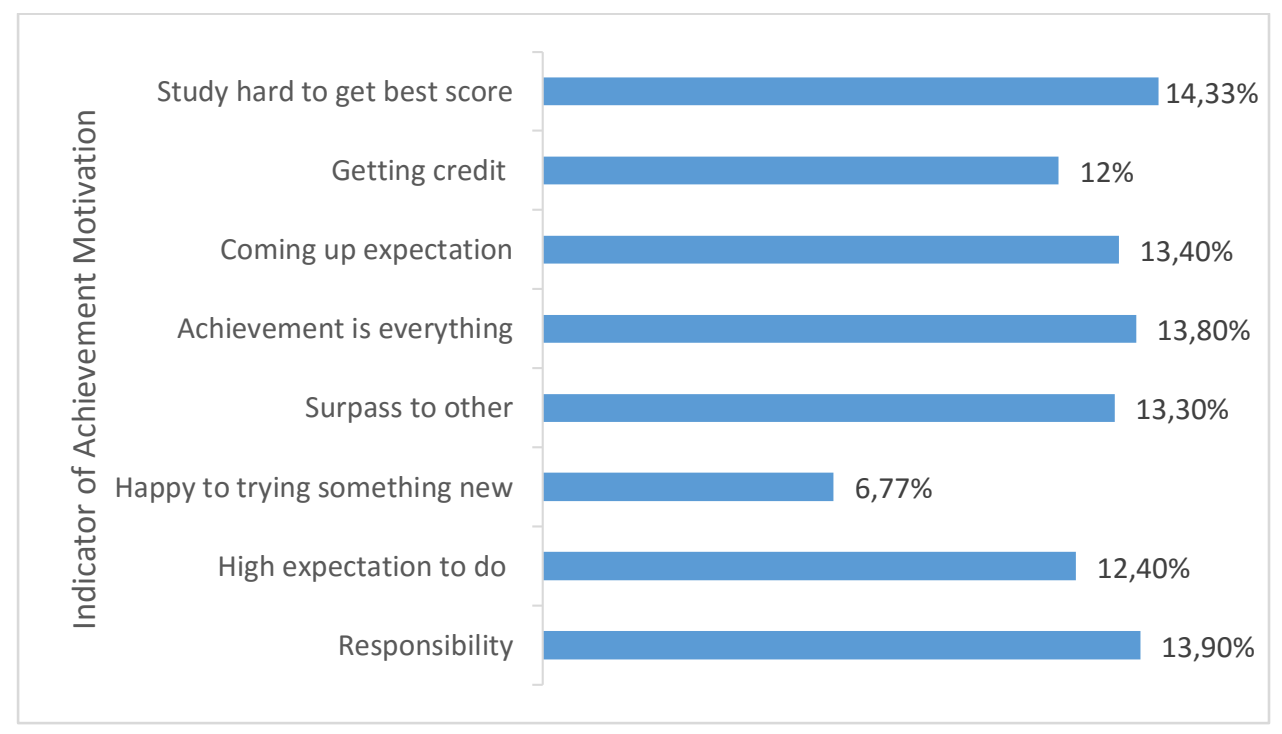

Figure 1. Percentage of achievement motivation indicator

The difference between student who has high motivation and low motivation is in cognitive test. Based on this test, student who has high motivation doing the test in a series, clear and readable. On the other hand, the cognitive test in students who has low motivation is not too clear. They still confuse to determine parent chain and alkyl and they do not memorize a few basic names of organic compound. Whereas, someone who 
has high motivation always study hard to get best scores, in this case is memorize the important point of their study, including a few basic names of organic compound. Sample of cognitive test by student who has low motivation and high motivation show in Fig 2 and Fig 3.

The percentage of comparison student's achievement and achievement motivation is shown in Fig 4. Based on Fig 4., Category of student's achievement and achievement motivation consist of very low, low, moderate, high, and very high. Percentage of achievement's motivation start by $0 \%$ in very low criteria. Then, the percentage still unchanged at $0 \%$ in low criteria. Furthermore, in moderate criteria, the histogram move up by $13,12 \%$. After that, the histogram rises significantly at $47,54 \%$ in high criteria then fell at $39,34 \%$ in very high criteria. Different with a percentage of achievement motivation, a percentage of student's achievement begin at $16,39 \%$ in very low criteria. The histogram rise so slowly by $21,31 \%$ in low criteria; $22,95 \%$ in moderate criteria then at $26,23 \%$ in high criteria. Furthermore, the percentage of student's achievement decrease at $13,12 \%$ in very high.

In the category of "high," achievement motivation earn the highest score. Similarly, the value of learning achievement. Learning achievement scores also had the highest score in the category of "high." The trend is not applicable on a bar chart with a different category. In the category of "very high," the percentage of achievement motivation is inversely proportional to the percentage of the value of student achievement.

In the category of "medium," the value of achievement motivation and learning achievement has a difference of 9,83\%. Furthermore, in the category of "very low" and "low," the value of achievement motivation and learning the value of the opposite interpretation. This shows that there is influence between student achievement motivation and student achievement though small influence. The significant differences between student's achievement and achievement motivation are random. 
3. Berilah nama IUPAC dari struktur senyawa di bawah ini<smiles>C=C(C)CC</smiles>

Jawaban :

2 - metil propana<smiles>CCC(C)C</smiles>

Jawaban:

Helesana 2 pentana

4. Tuliskan struktur kimia dari nama senyawa

a. 4-metil-2,3-dikloropentana Jawaban :

$\underset{H}{H}-\frac{H}{C}-\frac{C}{C}-\frac{1}{C}-\frac{H}{1}-\frac{H}{1}-\frac{1}{C}-\frac{1}{C}-C_{3}$

b. 2 metil, 3-butanol Jawaban :

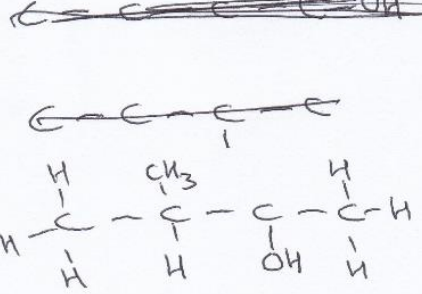

Figure 2. Cognitive test for students who has low motivation
3. Berilah nama IUPAC dari struktur senyawa di bawah ini<smiles>C=C(C)CC</smiles>

Jawaban: 2 metil-1-Behtena

b.<smiles>CC(C)C(C)C</smiles>

Jawaban: 2,3 -metil butana

4. Tuliskan struktur kimia dari nama senyawa

a. 4-metil-2,3-dikloropentana Jawaban :

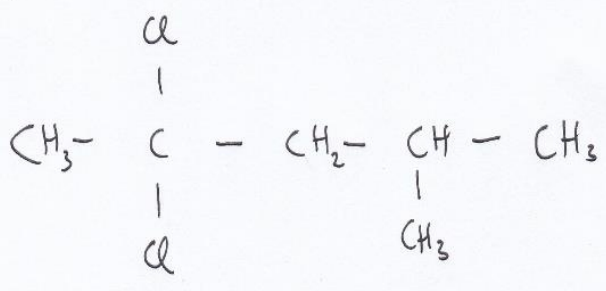

b. 2 metil, 3-butanol Jawaban:

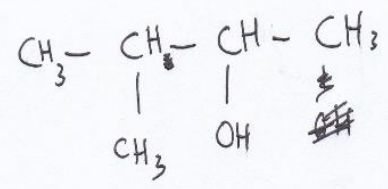

Figure 3. Cognitive test for students who has high motivation 


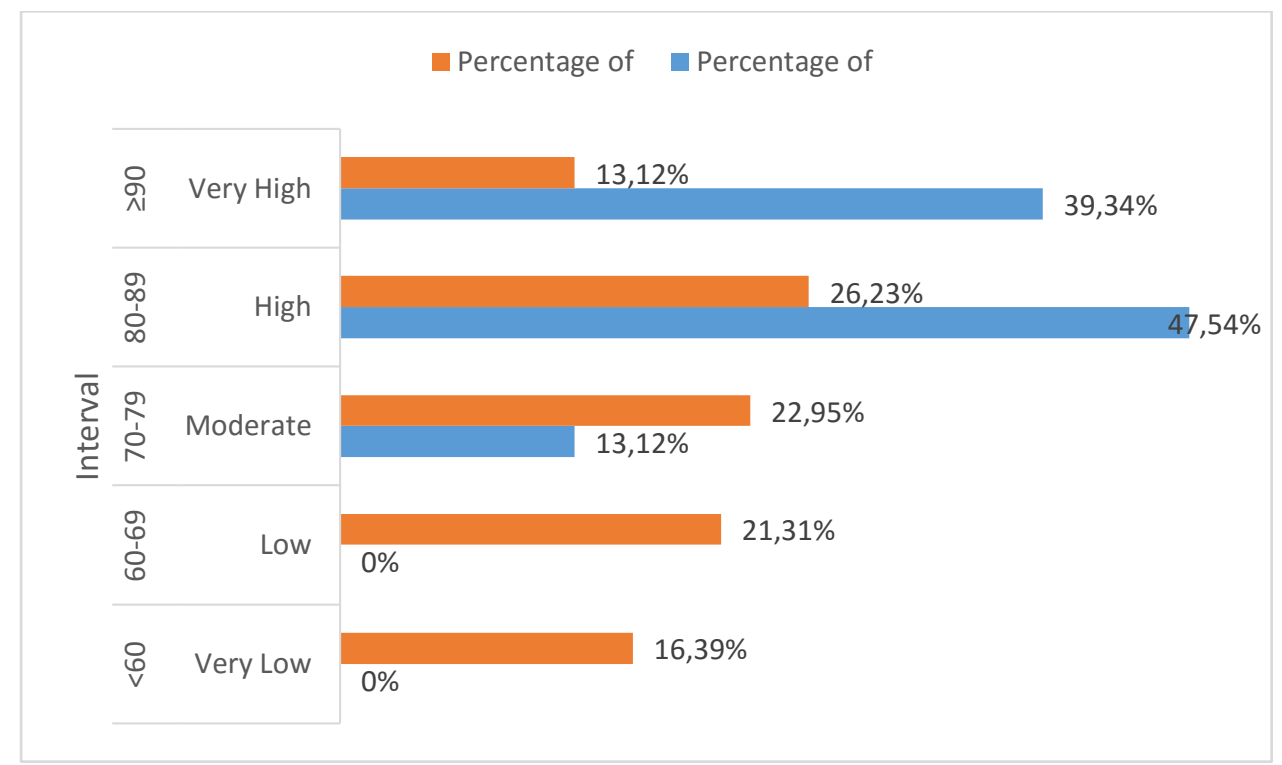

Figure 4. Comparison category between student's achievement and achievement motivation

This is very different from the theory that the characteristics of students that can influence learning outcomes are the achievement motivation. To achieve the best results needed good condition along with the hope of success to obtain optimal results. Achievement motivation as part of an intrinsic motivation that has a strong influence on the achievement of learning outcomes. Hopes, desires, and efforts of students arising from the students as the propulsive energy of all activities for learning. The existence of such energy will follow the students' learning in earnest and completing tasks with good learning, to obtain optimal learning results [11].

Waridiyati (in Taiyeb: 2012) [4], the research revealed that there is a significant correlation between motivation and student achievement in the study of Islamic Education subject areas even if the level of correlation is relatively weak or low. High achievement motivation is called when the desire for success is greater than the fear of failure. People who have high achievement motivation tends to have high expectations for success, especially when faced with the task of risk and difficulty level is moderate and difficult. Daft in Moore et al said that need for achievement consist of success pretension, break a way, finishing difficulties and pretention to surpass the other [12]. In contrast to the low achievement motivation of people, tend to avoid the task of intermediate risk, because the task of intermediate risk will cause great anxiety, so have the easiest task or difficult. The easiest task to give more chances to avoid failure. According to Atkinson in Velmurugan et.al [9] here are two aspects of the underlying motivation of achievement that rewards for success and avoid failure.

Motivation encourages individuals to achieve success and aim to succeed in the competition or rivalry with some measure of excellence (standard of excellence). The size of that advantage may be its own previous accomplishments or the accomplishments of others (McClellend in Velmurugan) [9]. 
Conclusion, the results show that achievement motivation on XI grade of SMK Kesehatan Rahani Husada students is in the category of achievement motivation "high" at $47,54 \%$. The high motivation of students because they have motivation to get high scores. The percentage of achievement motivation indicator in "study hard to get high score" as $14,33 \%$. Although, achievement motivation tends effect is random to student's achievement.

\section{References}

[1] Media Indonesia 2015 Masuki MEA 2015, Tingkatkan Kualitas Sekolah dan Pendidikan Karakter, accessed 8 Februari 2015 from http://www.mediaindonesia.com/news/read/1884/masuki-mea-2015tingkatkan-kualitas-sekolah-dan-pendidikan-karakter/2015-03-27

[2] Akbar R and Hawadi 2001 Psikologi Perkembangan Anak - Mengenal Sifat, Bakat, dan Kemampuan Anak.(Jakarta: Grasindo) p 65

[3] Mokhtar MZ et al 2013 Motivation and Performance in Learning Calculus Through Problem-Based Learning International Journal of Asian Social Science 3 1999-05

[4] A. Mushawwir Taiyeb, Arsad Bahri, and Rezky Batari Razak 2012 Analisis Motivasi Berprestasi Siswa Sman 8 Makassar dalam Belajar Biologi Jurnal Bionature 13 77-82

[5] Uno HB 2013 Teori Motivasi dan Pengukurannya (Analisis di Bidang Pendidikan). Jakarta: Bumi Aksara

[6] Richard M. Ryan and Edward L. Deci 2000 Intrinsic and Extrinsic Motivations: Classic Definitions and New Directions Contemporary Educational Psychology 25 54-67

[7] Sugiyono 2010 Metode Penelitian Pendidikan (Pendekatan Kuantitatif, Kualitatif, dan $R \& D)$. (Bandung: Alfabeta) p 89

[8] Depdiknas 2009 Pengembangan Perangkat Penilaian Afektif (Jakarta: Kementrian Pendidikan Nasional) p 10

[9] Velmurugan K and Balakrishnan V 2013 Achievement Motivation of Higher Secondary Students in Relation to Locality and Type of Family. International Journal of Teacher Educational Research (IJTER) 2 2319-4642

[10] Barry J. Zimmerman 2000 Self-Efficacy: An Essential Motive to Learn Contemporary Educational Psychology 25 82-91

[11] Sujarwo Motivasi Berprestasi Sebagai Salah Satu Perhatian dalam Memilih Strategi Pembelajaran (Yogyakarta: Universitas Negeri Yogyakarta) p 2

[12] Moore LL, Grabsch DK and Rotter C 2010 Using Achievement Motivation Theory to Explain Student Participation in a Residential Leadership Learning Community Journal of Leadership Education 9 